\title{
PRIVATE ELECTRIC MOBILITY AND EXPECTED IMPACTS ON CLIMATE AND AIR QUALITY
}

\author{
MARCO SCHIAVON, LUCA ADAMI \& MARCO RAGAZZI \\ Department of Civil, Environmental and Mechanical Engineering, University of Trento, Italy
}

\begin{abstract}
The transition towards electric mobility is expected to reduce the direct emissions of local pollutants and greenhouse gases (GHGs) from road transport. However, the environmental sustainability of road traffic is also influenced by the level of sustainability of the sources that compose the grid mix used to charge electric vehicles. The present paper aims at understanding if electric mobility can improve air quality and reduce the emissions of global and local air pollutants even if this transition is not supported by a continuous increase in the share of renewable sources in the grid mix. To answer this research question, two scenarios were evaluated through the application of emission and dispersion modelling: (1) a present-case scenario characterized by the movement of vehicles whose composition matches the latest statistics on the Italian vehicle fleet and (2) a future-case scenario entirely composed of battery electric vehicles (BEVs). Both scenarios considered the same study area: a portion of an Italian urban area characterized by the presence of a canyon-like street. To take the comparison to extremes, the few BEVs in the present-case scenario were assumed as fed by renewable energy, while a nearby coal power plant was considered as the power source for the future-case BEVs. In spite of its deplorable energy source (coal) for BEVs, the future-case scenario would allow saving $12 \%$ GHG emissions with respect to the present-case scenario. The maximum annual mean concentrations of nitrogen oxides and total suspended particles in the future-case scenario were $99.9 \%$ and $68.0 \%$ lower in the street canyon compared to the present-case scenario. However, depending on the power plant considered, additional pollutants may be emitted, which may worsen the local air quality, especially if the location, the size and the characteristics of the emission source are not adequately evaluated.

Keywords: air pollution, air quality, AUSTAL2000, carbon balance, dispersion modelling, emissions, environmental sustainability, road traffic, sustainable mobility, urban street canyon.
\end{abstract}

\section{INTRODUCTION}

Road traffic is a known source of several air pollutants, including nitrogen oxides (NOx), coarse (PM10) and fine (PM2.5) particulate matter, volatile organic compounds (VOCs), carbon monoxide $(\mathrm{CO})$, polycyclic aromatic hydrocarbons and heavy metals. According to the latest report on air quality in the European Union (EU) [1], road traffic is responsible for $39 \%$ NOx, 20\% CO, 11\% PM2.5, 10\% PM10 and 8\% non-methane VOC direct emissions in the EU-28 countries. Road traffic being a key contributor of NOx, this sector is one of the main factors responsible for secondary PM formation [2]. Road transport contributes more than $70 \%$ of the emissions of greenhouse gases (GHGs) from the transportation sector, which is responsible for $23 \%$ of the total energy-related GHG emissions [3].

The recent SARS-COV-2 outbreak and the drastic measures undertaken by governments to reduce the mobility of citizens have significantly decreased the ambient air concentrations of air pollutants, especially in the most polluted areas and during the first phases of the pandemic [4]. However, the recovery of anthropic activities after the first months of the COVID-19 emergency poses the risk that the emissions of air pollutants may reach or even exceed the previous levels [5]. Given the role of road traffic in the overall emission framework, planning strategies for sustainable mobility is mandatory. The implementation of sustainable mobility strategies is expected to contribute to two sustainable development goals (SDGs) listed 
in the United Nations' 2030 Agenda: 'Sustainable cities and communities' (SDG n. 11) and 'Climate action' (SDG n. 13) [6]. In the EU, the European Green Deal includes two specific policies ('2.1.3 Mobilising industry for a clean and circular economy' and '2.1.5 Accelerating the shift to sustainable and smart mobility') that explicitly consider the need for sustainable mobility strategies and the transition towards electric and zero-emission mobility [7]. The desirable replacement of internal combustion vehicles with electric vehicles would reduce the contribution of road transport to the direct emissions of global and local air pollutants. However, this transition would result as incomplete if the electric energy production continued to depend on fossil fuels. Thus, the following question arises: can electric mobility improve air quality and reduce the emissions of global and local air pollutants if not supported by a continuous increase in renewable energy production?

The present paper is an attempt to answer the previous question. This paper aims at clarifying the impacts of mobility in terms of emissions of local and global pollutants in the present state and in 2050, i.e., the year in which the EU expects that all road vehicles will be battery electric vehicles (BEVs) [8]. Two scenarios for road transport were analysed: (1) a present-case scenario considering the 2019 vehicle fleet of Italy and (2) a future scenario considering the vehicle fleet as entirely composed of BEVs. To consider the most unfavourable conditions to electric mobility and take the comparison to extremes, the electric energy required by BEVs in the present and future scenarios is assumed as supplied by renewable energy sources and a coal power plant, respectively. The purpose is to highlight the positive contribution of electric mobility to air quality regardless of the environmental sustainability of electric energy production. To evaluate the impacts of mobility on the local air quality, this paper presents a hypothetical case study concerning a small urban area characterized by canyon-like streets and by meteo-climatic conditions typical of northern Italy, with frequent episodes of atmospheric stability. A hypothetical coal power plant is located at a distance of $450 \mathrm{~m}$ from the urban area, and is assumed as the supplier of the electric energy required by BEVs. Dispersion simulations are carried out with the AUSTAL2000 dispersion model and will compare the present and future scenarios in terms of air quality. NOx, total suspended particles (TSPs) and sulphur dioxide $\left(\mathrm{SO}_{2}\right)$ are selected as representative pollutants emitted from road traffic and the power plant. Besides a comparison in terms of air quality, the present paper aims at comparing the emissions of GHGs in the present situation and in the future.

\section{MATERIAL AND METHODS}

\subsection{Study area}

The study area consists of a portion of a neighbourhood of Verona (Italy). Verona is located in northern Italy in the Po valley and is characterized by a continental climate, partially mitigated by the presence of the nearby Lake Garda. As many other towns and cities in the Po valley, Verona is characterized by frequent thermal inversion episodes, especially during winter, which favour the permanence of air pollutants near the ground under stable atmospheric conditions. The study area hosts a canyon-like street whose hourly traffic conditions were retrieved from a previous work of the authors [9], resulting in 2,901,070 transits per year. A raster map of the buildings was prepared for the application of the dispersion model. The width $(\mathrm{W})$ of the canyon-like street varies between 4.6 and $31.4 \mathrm{~m}$. The height $(\mathrm{H})$ of the buildings is in the range 3-19 $\mathrm{m}$. The $\mathrm{H} / \mathrm{W}$ ratio along the street canyon varies between 0.3 and 3.2. Close to the study area and $500 \mathrm{~m}$ far from the street canyon in the West direction, a 
hypothetical coal power plant is located. The height of the stack and the off-gas velocity are assumed as equal to $40 \mathrm{~m}$ and $10 \mathrm{~m} / \mathrm{s}$, respectively.

\subsection{Emission calculation}

\subsubsection{Road traffic}

Emission factors (EFs) of on-road vehicles are available in the COPERT 5 software [10], which is the standard vehicle emission calculator of the EU. COPERT 5 allows for the calculation of the emission of several air pollutants emitted from 372 vehicle classes grouped into five categories (passenger cars (PCs), light commercial vehicles (LCVs), heavy-duty trucks, buses and mopeds and motorcycles) and under different driving conditions and road slopes. The vehicle fleet used in the present paper is the Italian one. In order to quantify the expected environmental improvements related to the transition from fossil-fuel cars to BEVs in urban areas, the present paper considers emissions from PCs and LCVs as the most represented categories in the study area. The latest statistics on the fleet composition according to the COPERT 5 categories and classes were retrieved from a national database [11] and refer to year 2019. According to the latest statistics, in Italy, BEVs only account for $0.04 \%$ of the total number of PCs and LCVs, which are 39,539,137 and 4,208,301, respectively. Figure 1 presents the composition of these two categories in terms of fuel supply and European emission standard. From 1992, the EU introduced stricter emission standards for vehicles starting from the EURO 1 standards [12,13] until the current EURO 6 standards [14,15].

Although BEVs do not emit end-of-pipe gases, they are sources of particulate matter (PM). PM is emitted by both tyre and brake use. PM EFs, intended as TSPs, related to BEVs are available in the latest edition of the EMEP/EEA air pollutant emission inventory guidebook
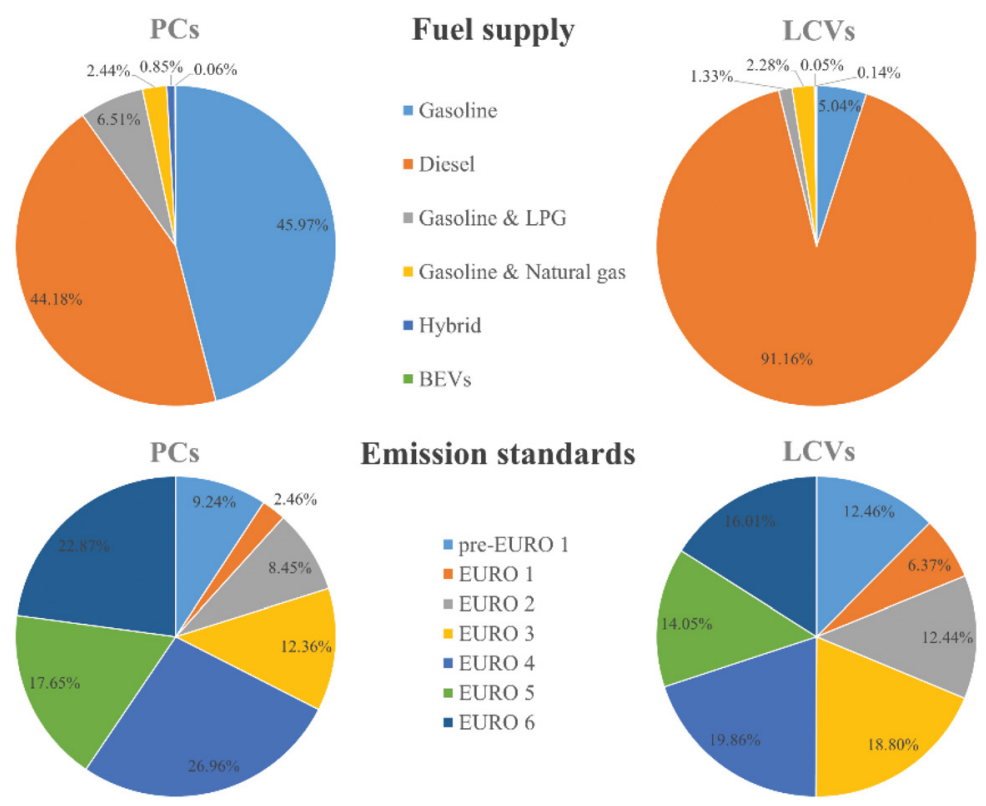

Figure 1: Composition of PCs and LCVs in Italy in 2019 in terms of fuel supply and emission standards [11]. 
of the European Environment Agency (EEA) [16]. Specifically, the TSP EFs related to tyre and brake wear are, respectively, 0.0107 and $0.0075 \mathrm{~g} / \mathrm{km}$ for PCs and 0.0169 and $0.0117 \mathrm{~g} /$ $\mathrm{km}$ for LCVs. In addition, all types of vehicles indirectly release TSP by road surface wear. According to the EEA [16], the TSP EF for both PCs and LCVs related to road surface wear is $0.0150 \mathrm{~g} / \mathrm{km}$.

\subsubsection{Electric energy production}

Data on the Italian average grid mix were retrieved by Italian Energy Management Service (GSE) and refer to the latest available statistics, i.e., year 2019 [17]. The 2019 carbon dioxide $\left(\mathrm{CO}_{2}\right) \mathrm{EF}$, referring to the electric energy consumed by the users, was calculated by considering the gross electric energy production from each source, the respective $\mathrm{CO}_{2}$ emissions and the grid losses [18] and resulted as equal to $304.9 \mathrm{~g} \mathrm{CO}_{2} / \mathrm{kWh}$.

As a precautionary measure, the comparison in terms of global and local air pollutants will consider a coal power plant in the future scenario and a renewable energy source with no emissions (e.g., a hydropower plant) in the present scenario. This choice is of course a precautionary measure to evaluate if BEVs may determine positive effects on human health and reduce GHG emissions, even in case the transition towards a higher share of renewable energy source does not take place. In the case of coal as an energy source, the local pollutants considered in this paper are NOx, TSPs, CO, sulphur oxides (SOx) and non-methane volatile organic compounds (NMVOCs). Table 1 presents the EFs referring to coal power stations and used in the dispersion simulations. By considering the national statistics, the $\mathrm{CO}_{2}$ EF related to coal power plants can be estimated as $1063.6 \mathrm{~g} \mathrm{CO}_{2} / \mathrm{kWh}$ of energy consumed by the users [18]. According to the Intergovernmental Panel on Climate Change, the contributions of other GHGs are negligible [19].

To estimate the emissions of global and local air pollutants related to the electric energy consumption of BEVs in the future scenario, an average value of specific electric energy consumption was retrieved in the literature. As recently estimated by Hoekstra [20], this value is $0.161 \mathrm{kWh} / \mathrm{km}$. Consequently, the EFs presented in Table 1 and related to the electric energy production for the operation of BEVs can be converted into grams per kilometre for a direct comparison with the EFs of the other types of vehicles (Table 2).

As a precautionary measure, and because the legislation imposes ambient air concentration limit values for $\mathrm{SO}_{2}$ instead of $\mathrm{SOx}$, the emissions of $\mathrm{SOx}$ from the plant were assumed as entirely composed of $\mathrm{SO}_{2}$. Considered the secondary role of $\mathrm{CO}$ and NMVOCs in terms of emissions from the power plant, the present paper will focus only on NOx, TSP and $\mathrm{SO}_{2}$. It is worth mentioning that COPERT 5 considers as null the emissions of SOx from vehicles, thanks to the improvements in the reduction of the sulphur content of diesel fuel in the last decades.

Table 1: EFs of the selected local air pollutants related to the electric energy production by a coal power plant [16].

\begin{tabular}{ll}
\hline Pollutant & EF $[\mathrm{g} / \mathrm{kWh}]$ \\
\hline NOx & 2.00 \\
TSP & 0.11 \\
CO & 0.08 \\
SOx & 7.83 \\
NMVOCs & 0.01 \\
\hline
\end{tabular}


Table 2: EFs of the selected pollutants related to electric energy production by a coal power plant to cover the energy demand by BEVs in the future scenario.

\begin{tabular}{ll}
\hline Pollutant & EF $[\mathrm{g} / \mathrm{km}]$ \\
\hline NOx & 0.322 \\
TSP & 0.018 \\
$\mathrm{CO}$ & 0.013 \\
$\mathrm{SOx}$ & 1.261 \\
$\mathrm{NMVOCs}$ & 0.002 \\
$\mathrm{CO}_{2}$ & 171.2 \\
\hline
\end{tabular}

\subsection{Dispersion modelling}

AUSTAL2000 was selected as the dispersion model to run the dispersion simulations because of its capability of computing both orography and the presence of buildings through the explicit definition of the geometry of the obstacles [21]. The model consists of (1) a diagnostic meteorological module (TalDIA) that computes the wind field based on a parameterization of atmospheric stability and (2) the dispersion module that computes the concentrations by counting the particles in each cell. The dispersion domain used in the present paper is a rectangular area measuring $880 \times 1400 \mathrm{~m}$. In the urban area, the cell size was set to $5 \mathrm{~m}$ in order to better resolve the wind field and dispersion calculations within the urban street canyon considered in the study area. A building map was provided to the model in order to consider building effects. Three additional nested grids were defined with decreasing resolution $(10,20$ and $40 \mathrm{~m})$ to simplify the computation outside the urban area in the current scenario and in the future scenario for TSP (Fig. 2). The remaining simulations, concerning only the power plant as emission source, were carried out with a single grid with cell size of 40. The building map was provided too. In this case, AUSTAL2000 automatically computes the dispersion by defining suitable nested grids and recalculates the output maps according to the resolution chosen by the user.

Meteorological data consist of 1 year of hourly observations of wind speed, wind direction and Klug/Manier stability class, which were retrieved from a local meteorological station and elaborated. Figure 3 presents the wind rose and the frequency of the Klug/Manier stability classes related to the local meteorological station. The Klug/Manier classification describes atmospheric stability through six classes from very stable (I) to very unstable (V) conditions. Two classes, III/1 and III/2, refer to stable-to-neutral and neutral-to-unstable conditions. Regarding the pollutants considered in this paper, due to the relatively low emissions of NMVOCs and CO, the dispersion simulations were carried out only on NOx, TSP and $\mathrm{SO}_{2}$. Since the $\mathrm{SO}_{2}$ EFs provided by COPERT 5 for PCs and LCVs are null, only the dispersion of NOx and TSP will be simulated in the present-case scenario.

The urban street canyon was modelled as a series of consecutive linear sources following the route of the street. The coal power plant was modelled as a point source with a release height of $40 \mathrm{~m}$, a stack diameter of $1.5 \mathrm{~m}$ and an off-gas temperature of $180{ }^{\circ} \mathrm{C}$. Regarding the emissions of air pollutants from vehicles, hourly values of NOx and TSP emissions (expressed as grams per second) were calculated as follows: 

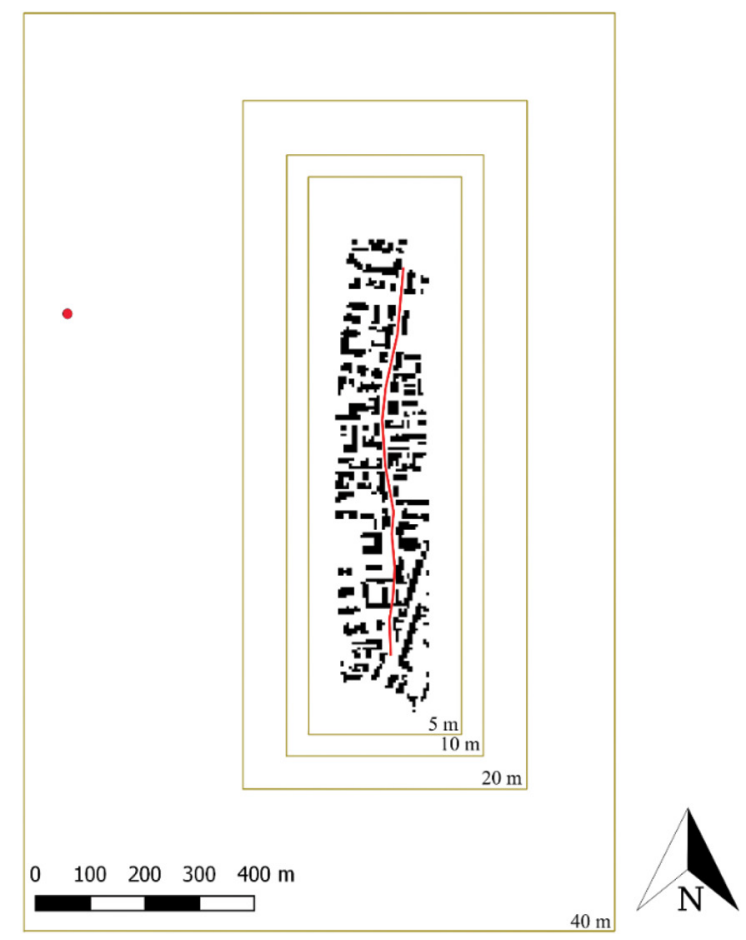

Figure 2: Study area with the computational domain, the building raster map, the street canyon highlighted and the location of the coal power plant.
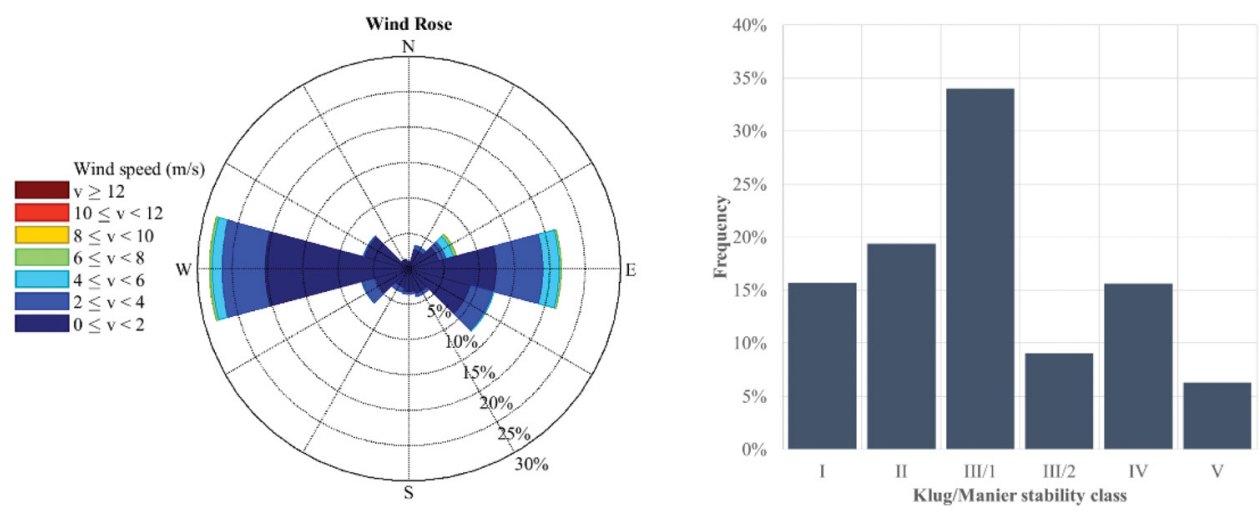

Figure 3: Wind rose and frequency of the Klug/Manier stability classes derived from the local meteorological station used in the dispersion modelling.

1. For each hour, the number of vehicles belonging to the $i$ COPERT 5 class moving along the street canyon was calculated by multiplying the total number of vehicle transits at that specific hour by the percentage of vehicles belonging to the $i$ class with respect to the whole vehicle fleet. 
2. For each hour, for each stretch of road and for each $i$ class, the EF related to the $j$ pollutant was multiplied by the length of the road stretch to give the hourly emission.

3. For each $j$ pollutant and for each road stretch, the hourly emissions from all vehicle classes were summed up to give the total hourly emissions.

4. For each $j$ pollutant and for each road stretch, hourly emissions were converted into grams per second as requested by AUSTAL2000.

The emissions from the coal plant (future scenario) were calculated by assuming that the plant provides electric energy to the BEVs moving along the street canyon, which generate $2,901,070$ transits per year. The emissions from the plant are assumed as constant emissions during the whole simulation period ( 8,760 hours) and were calculated by multiplying the EFs of NOx, TSP and SOx (Table 2) by the number of BEV transits in the future scenarios and the length of the street canyon.

\section{RESULTS AND DISCUSSION}

\subsection{Expected GHG emissions}

To estimate the annual $\mathrm{CO}_{2}$ equivalent emissions $\left(\mathrm{CO}_{2 \mathrm{eq}}\right)$ from road traffic, the total $\mathrm{CO}_{2}$ EFs (including the EFs related to lube oil consumption), the methane $\left(\mathrm{CH}_{4}\right)$ and nitric oxide $\left(\mathrm{N}_{2} \mathrm{O}\right)$ EFs were retrieved for each vehicle class. To obtain $\mathrm{CO}_{2 \mathrm{eq}} \mathrm{EFs}$ for each class, the classspecific $\mathrm{CH}_{4}$ and $\mathrm{N}_{2} \mathrm{O}$ EFs were multiplied by their global warming potentials, which are, respectively, 28 and 265 [22]. For each vehicle class, through the available statistics on the vehicle fleet [11], the total annual number of transits along the street canyon was calculated, and the latter was multiplied by the class-specific $\mathrm{CO}_{2 \mathrm{eq}} \mathrm{EF}$ and by the length of the street canyon. The total annual $\mathrm{CO}_{2 \mathrm{eq}}$ emissions were obtained by summing up the results over the vehicle classes considered, resulting in $438 \mathrm{t}$ /year in the present-case scenario. By multiplying the $\mathrm{CO}_{2} \mathrm{EF}$ from coal power plants (Table 2) by the length of the street canyon and by the expected number of BEVs moving along the canyon in 2050 (which is assumed as equal to the current total number of vehicles), the $\mathrm{CO}_{2 \mathrm{eq}}$ emission from the coal power plant covering the energy demand of the vehicles along the canyon is $385 \mathrm{t} / \mathrm{year}$. In conclusion, powering BEVs with the electric energy generated by a power source characterized by a low level of sustainability (coal plant) would allow saving $12 \%$ GHG emissions with respect to the operation of the same number of vehicles of the present-case scenario, i.e., mainly diesel- and petrol-fuelled vehicles.

\subsection{Expected impacts on air quality}

NOx annual mean concentrations reach the maximum value of $42.1 \mu \mathrm{g} / \mathrm{m}^{3}$ at the southern stretch of the urban street canyon (Fig. 4a). In general, the NOx annual mean concentrations maintain at values $>11.5 \mu \mathrm{g} / \mathrm{m}^{3}$ within the street canyon. Except for vegetation, for which an annual mean concentration limit value exists in the EU $\left(30 \mu \mathrm{g} / \mathrm{m}^{3}\right)$, no limit value is set for human health, since the toxic compound among NOx is nitrogen dioxide $\left(\mathrm{NO}_{2}\right)$. However, it is possible to obtain a preliminary estimation of the annual mean $\mathrm{NO}_{2}$ concentration within the street canyon by applying the simplified $\mathrm{NOx} / \mathrm{NO}_{2}$ conversion formula by Düring et al. [23], which requires the annual mean concentrations of NOx and ozone $\left(\mathrm{O}_{3}\right)$ measured by a background station close to the study area. Based on the formulation of Düring et al. 
[23] and on the data provided by the Environmental Protection Agency of Veneto Region (ARPAV), $\mathrm{NO}_{2}$ annual mean concentrations of up to $34.6 \mu \mathrm{g} / \mathrm{m}^{3}$ may be achieved within the street canyon. Such value is close to the annual mean concentration limit value $\left(40 \mu \mathrm{g} / \mathrm{m}^{3}\right)$ set by the EU [24]. The annual mean concentrations of TSP in the present-case scenario are presented in Fig. $4 \mathrm{~b}$. The maximum concentration $\left(5.0 \mu \mathrm{g} / \mathrm{m}^{3}\right)$ occurs halfway within the canyon.

Figure 5 shows the annual mean concentrations of NOx (Fig. 5a) and TSP (Fig. 5b) in the future-case scenario. The maximum NOx and TSP annual mean concentrations are 0.05 and $1.6 \mu \mathrm{g} / \mathrm{m}^{3}$, respectively, resulting in a respective concentration reduction of $99.9 \%$ and $68.0 \%$ compared to the present-case scenario. This is mainly due to the dilution effect of the plume emitted by the coal power plant. The higher contribution of TSP compared to NOx is due to the emission of particles from tyre and brake use and road surface wear, which are generated within the street canyon. Moving the power source outside the urban fabric and changing the release of the plume from multiple ground-level sources confined in a canyon to a single upper source brings evident environmental benefits to the urban area in terms of air quality. $\mathrm{Road} /$ tyre/brake wear, which is unavoidable even with BEVs, contributes to about $32 \%$ of the TSP concentration induced by road traffic in the present-case scenario and $>99 \%$ of the TSP concentration induced by the power plant and BEVs in the future-case scenario. However, there are significant uncertainties regarding TSP emissions from BEVs. On one hand, the regenerative braking of electric vehicles allow reducing TSP emissions compared to internal combustion engine (ICE) vehicles, but electric vehicles are about $20 \%$ heavier than ICE vehicles [25]. In addition, the greater mass may increase the TSP emission from tyre and road wear. According to Beddows and Harrison [25], TSP emissions from brake, road and tyre wear may be about $30 \%$ higher compared to ICE vehicles. At present, the EU does not provide specific EFs for BEVs.

Although the emissions of NOx and TSP seem to give negligible contributions within the urban fabric, SOx emissions may imply potential air quality issues. Figure 6 shows the $\mathrm{SO}_{2}$ concentrations in the future scenario in terms of maximum daily mean values exceeded 3 times in a year (Fig. 6a) and maximum hourly mean values exceeded 24 times in a year (Fig. 6b), which must be compared with 125 and $350 \mu \mathrm{g} / \mathrm{m}^{3}$, respectively, according to the EU legislation [24]. As presented in Fig. 6, the maximum values are 0.5 and $1.6 \mu \mathrm{g} / \mathrm{m}^{3}$, respectively, for the maximum daily mean exceeded 3 times in a year (Fig. 6a) and maximum hourly mean exceeded 24 times in a year. Similar to the case of NOx emitted by the coal power plant, the maximum $\mathrm{SO}_{2}$ concentrations occur in the proximity of the northern part of the urban fabric considered. It must be noticed that, as a precautionary measure, SOx emissions were assumed as equal to $\mathrm{SO}_{2}$ emissions. However, it is unlikely that a power plant supplies only the energy requested by the vehicles moving along one road. Thus, the choice of the power source and its location requires a detailed environmental assessment based on the energy consumption the plant is designed to cover. For instance, the maximum $\mathrm{SO}_{2}$ daily mean exceeded 3 times in a year could be exceeded if the plant is requested to provide the electric energy to charge a number of vehicles that is 250 times the number of vehicles that move along the street canyon considered in this paper. In addition, the power plant chosen in this study emits pollutants (SOx) that road vehicles do not release.

Considered the latest statistics on the annual average per-capita electrical energy consumption in Italy $(5,022 \mathrm{kWh})[26,27]$, the Italian population $(60,421,797)$ [27], the annual average mileage per vehicle in Italy $(9,460 \mathrm{~km})$ [28], the total number of PCs and LCVs in Italy $(43,747,438)[11]$ and the average BEV energy consumption $(0.161 \mathrm{kWh} / \mathrm{km})[20]$, the per-capita electric energy consumption is expected to increase by about $20 \%$ when the 

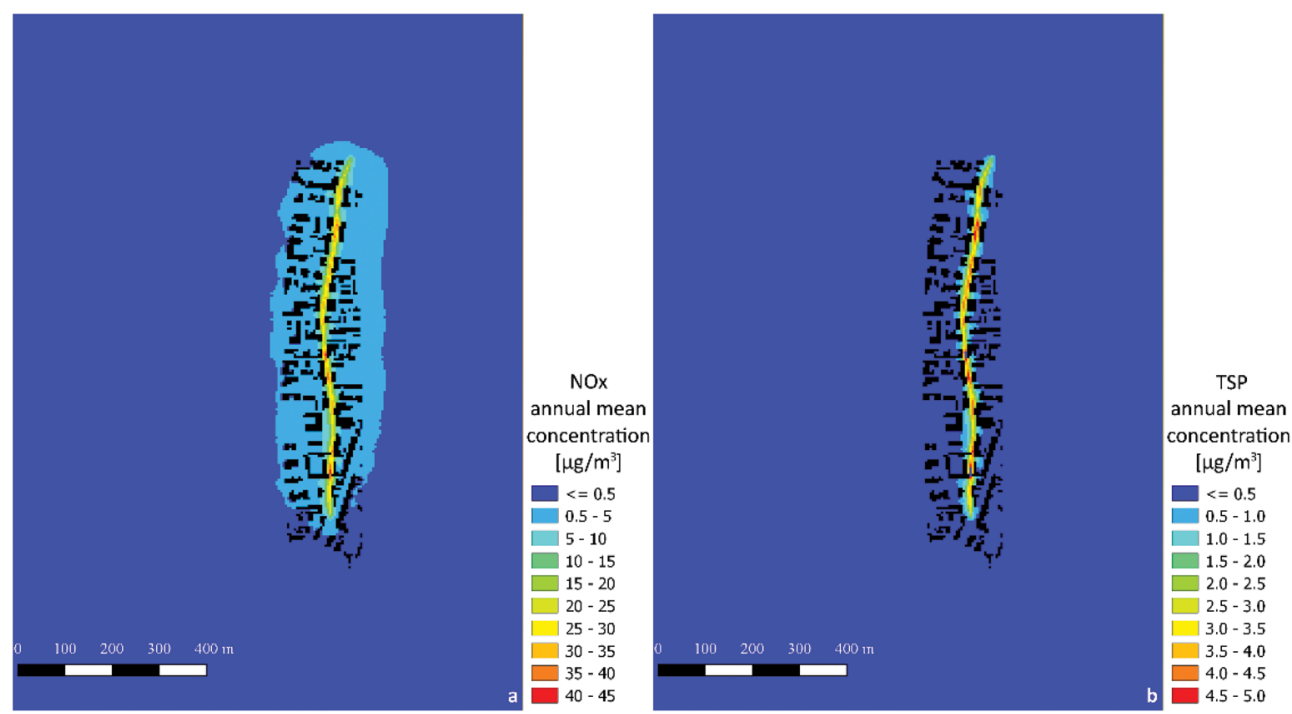

Figure 4: (a) NOx and (b) TSP annual mean concentration maps in the present-case scenario.
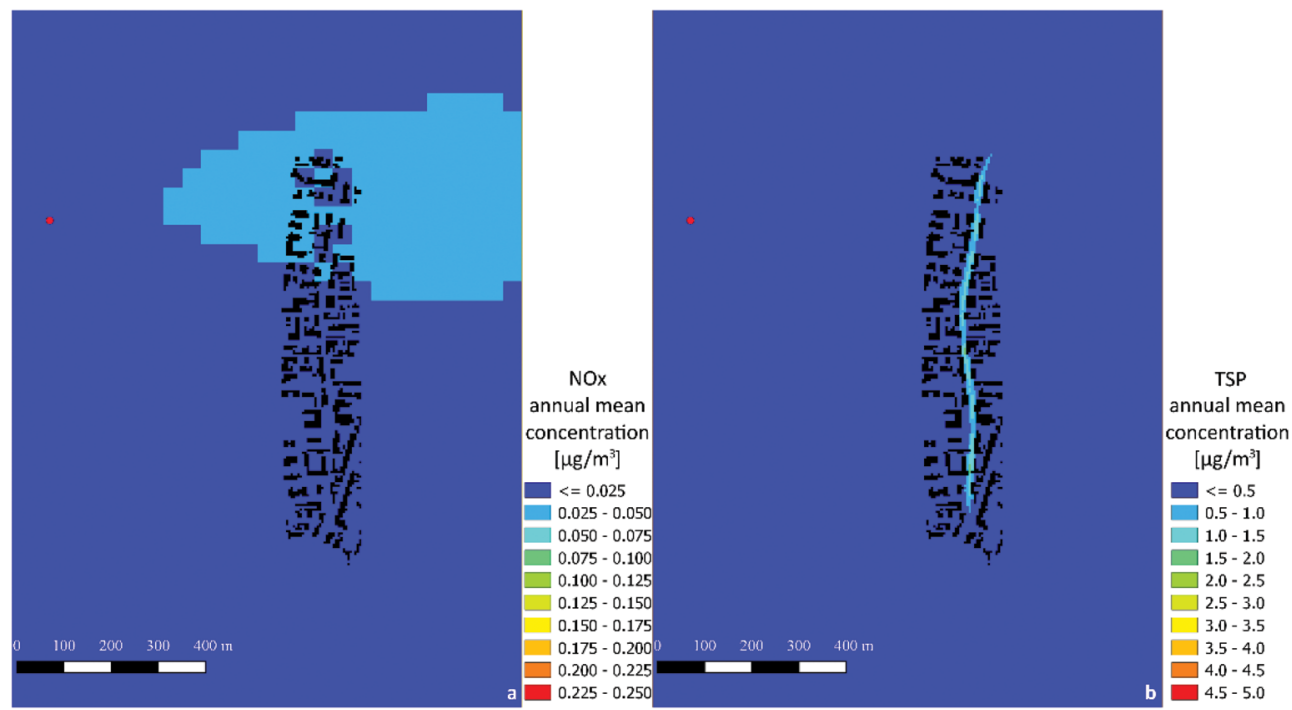

Figure 5: (a) NOx and (b) TSP annual mean concentration map in the future scenario, with the location of the power plant highlighted.

transition to BEVs will be completed. This may require the installation of additional power plants. Governments may decide either to improve the existing plants or to build new ones. If the latter alternative is chosen and if renewable sources are not available, this could be the occasion to build smaller plants that may increase the level of acceptance by the population. However, the local impacts should be assessed to exclude a worsening in the air quality conditions with respect to improving one single plant. 


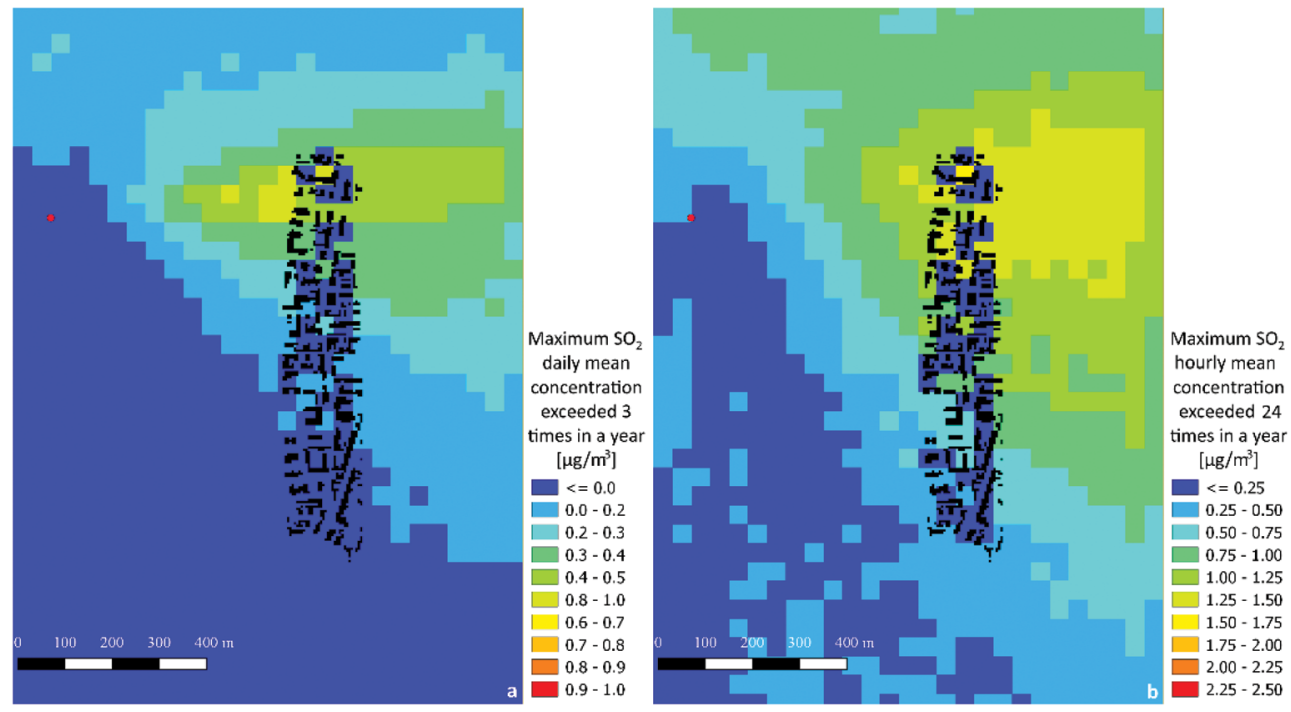

Figure 6: Maps of the maximum $\mathrm{SO}_{2}$ (a) daily mean concentration exceeded 3 times in a year and (b) hourly mean concentration exceeded 24 times in a year, in the future scenario, with the location of the power plant highlighted.

\section{CONCLUSIONS}

The present study highlighted the potentials of electric mobility in terms of reduced impacts on air quality and the climate. Even choosing an undesired source of energy (coal) translates into lower GHG emissions when shifting from the current vehicle fleet to a whole fleet composed of BEVs. Moving the emission source outside the urban fabric allows for substantial reductions in the emission of the air pollutants emitted from vehicles. However, depending on the power plant considered, additional pollutants may be emitted. In fact, in spite of the improvements achievable when shifting towards a vehicle fleet entirely composed of BEVs, air quality may be affected by the choice of the source for electric energy production. The present paper considers a power plant designed to cover the energy demand by the vehicles moving within the study area in the future-case scenario. This represents a limitation of this study since a power plant would be designed to cover higher energy needs than those related to the BEVs moving along a street. For this reason, the choice of the size, location and characteristics of the emission source cannot leave a detailed environmental impact assessment out of consideration.

\section{ACKNOWLEDGEMENTS}

The authors wish to thank the Environmental Protection Agency of Veneto Region for sharing the air quality and meteorological data used in this research.

\section{REFERENCES}

[1] European Environment Agency, Air Quality in Europe - 2020 Report, European Environment Agency, available at https://www.eea.europa.eu/publications/air-qualityin-europe-2020-report (accessed 8 February 2021). 
[2] Gualtieri, G., Carotenuto, F., Finardi, S., Tartaglia, M., Toscano, P. \& Gioli, B., Forecasting PM10 hourly concentrations in northern Italy: Insights on models performance and PM10 drivers through self-organizing maps. Atmospheric Pollution Research, 9, pp. 1204-1213, 2018.

[3] Edenhofer, O., Pichs-Madruga, R., Sokona, Y., Farahani, E., Kadner, S., Seyboth, K., Adler, A., Baum, I., Brunner, S., Eickemeier, P., Kriemann, B., Savolainen, J., Schlömer, S., von Stechow, C., Zwickel, T. \& Minx, J.C., (eds), Climate Change 2014: Mitigation of Climate Change. Contribution of Working Group III to the Fifth Assessment Report of the Intergovernmental Panel on Climate Change, Cambridge University Press: Cambridge and New York, 2014.

[4] Kumar, P., Hama, S., Omidvarborna, H., Sharma, A., Sahani, J., Sisay, K.V.A., Debele, E., Zavala-Reyes, J.C., Barwise, Y. \& Tiwari, A. Temporary reduction in fine particulate matter due to 'anthropogenic emissions switch-off' during COVID-19 lockdown in Indian cities. Sustainable Cities and Society, 62, 102382, 2020.

[5] European Parliament, Texts adopted - Implementation of the Ambient Air Quality Directives, European Parliament, available at https://www.europarl.europa.eu/doceo/ document/TA-9-2021-0107_EN.html (accessed 31 March 2021).

[6] United Nations, Sustainable Development Knowledge Platform, United Nations, available at https://sustainabledevelopment.un.org/ (accessed 28 February 2021).

[7] EUR-Lex, Communication from the Commission - The European Green Deal, EURLex, available at https://eur-lex.europa.eu/legal-content/EN/TXT/?qid=159644391191 3\&uri=CELEX:52019DC0640\#document2 (accessed 7 April 2021).

[8] EUR-Lex, A Clean Planet for all - A European Strategic Long-Term Vision for a Prosperous, Modern, Competitive and Climate Neutral Economy, EUR-Lex, available at https://eur-lex.europa.eu/legal-content/EN/TXT/?uri=CELEX:52018DC0773 (accessed 31 March 2021).

[9] Schiavon, M., Redivo, M., Antonacci, G. Rada, E.C., Ragazzi, M., Zardi, D. \& Giovannini, L., Assessing the air quality impact of nitrogen oxides and benzene from road traffic and domestic heating and the associated cancer risk in an urban area of Verona (Italy). Atmospheric Environment, 120, pp. 234-243, 2015.

[10] EMISIA SA, Copert, EMISIA SA, available at https://www.emisia.com/utilities/copert/ (accessed 8 February 2021).

[11] Automobile Club d'Italia, ACI Studi e ricerche - Autoritratto 2019, Automobile Club d'Italia, available at http://www.aci.it/laci/studi-e-ricerche/dati-e-statistiche/ autoritratto/autoritratto-2019.html (accessed 9 February 2021).

[12] EUR-Lex, Council Directive 91/441/EEC of 26 June 1991 Amending Directive 70/220/ EEC on the Approximation of the Laws of the Member States Relating to Measures to be Taken Against Air Pollution by Emissions From Motor Vehicles, EUR-Lex, available at https://eur-lex.europa.eu/legal-content/en/ALL/?uri=CELEX\%3A31991L0441 (accessed 19 February 2021).

[13] EUR-Lex, Council Directive 93/59/EEC of 28 June 1993 Amending Directive 70/220/EEC on the Approximation of the Laws of the Member States Relating to Measures to be Taken Against Air Pollution by Emissions From Motor Vehicles, EURLex, available at https://eur-lex.europa.eu/legal-content/EN/ALL/?uri=uriserv:OJ .L_.1993.186.01.0021.01.ENG (accessed 19 February 2021).

[14] EUR-Lex, Commission Regulation (EU) No 459/2012 of 29 May 2012 Amending Regulation (EC) No 715/2007 of the European Parliament and of the Council and 
Commission Regulation (EC) No 692/2008 as Regards Emissions From Light Passenger and Commercial Vehicles (Euro 6) Text With EEA Relevance, EUR-Lex, available at https://eur-lex.europa.eu/legal-content/EN/TXT/?uri=celex\%3A32012R0459 (accessed 19 February 2021).

[15] EUR-Lex, Commission Regulation (EU) 2016/646 of 20 April 2016 Amending Regulation (EC) No 692/2008 as Regards Emissions From Light Passenger and Commercial Vehicles (Euro 6), EUR-Lex, available at https://eur-lex.europa.eu/legalcontent/en/TXT/?uri=CELEX\%3A32016R0646 (accessed 19 February 2021).

[16] European Environment Agency, EMEP/EEA Air Pollutant Emission Inventory Guidebook 2019, European Environment Agency, available at https://www.eea.europa. eu/publications/emep-eea-guidebook-2019 (accessed 12 February 2021).

[17] GSE, Fuel Mix - Determinazione del Mix Energetico per Gli Anni 2018-2019 (in Italian), GSE, available at https://www.gse.it/servizi-per-te/news/fuel-mix-determinazione-delmix-energetico-per-gli-anni-2018-2019 (accessed 15 February 2021).

[18] ISPRA, Fattori di Emissione per la Produzione ed il Consumo di Energia Elettrica in Italia (in Italian); ISPRA, available at http://www.sinanet.isprambiente.it/it/sia-ispra/ serie-storiche-emissioni/fattori-di-emissione-per-la-produzione-ed-il-consumo-dienergia-elettrica-in-italia/view (accessed 12 February 2021).

[19] 2006 IPCC Guidelines for National Greenhouse Gas Inventories - Chapter 2: Stationary Combustion; Intergovernmental Panel on Climate Change. Online, https://www.ipccnggip.iges.or.jp/public/2006gl/pdf/2_Volume2/V2_2_Ch2_Stationary_Combustion. pdf (accessed 12 March 2021).

[20] Hoekstra, A., The underestimated potential of battery electric vehicles to reduce emissions. Joule, 3, pp. 1412-1414, 2019.

[21] Umwelt Bundesamt, AUSTAL2000 - Program Documentation of Version 2.6, Umwelt Bundesamt, available at https://www.umweltbundesamt.de/sites/default/files/ medien/2008/dokumente/austal2000_en_0.pdf (accessed 16 February 2021).

[22] Stocker, T.F., Qin, D., Plattner, G.-K., Tignor, M., Allen, S.K., Boschung, J., Nauels, A., Xia, Y., Bex, V. \& Midgley, P.M., (eds.), Climate Change 2013: The Physical Science Basis. Contribution of Working Group I to the Fifth Assessment Report of the Intergovernmental Panel on Climate Change, Cambridge University Press: Cambridge, pp. 659-740, 2013.

[23] Düring, I., Bächlin, W., Ketzel, M., Baum, A., Friedrich, U. \& Wurzler, S., A new simplified $\mathrm{NO} / \mathrm{NO}_{2}$ conversion model under consideration of direct $\mathrm{NO}_{2}$-emissions. Meteorologische Zeitschrift, 20, pp. 67-73, 2011.

[24] Directive 2008/50/EC of the European Parliament and of the Council of 21 May 2008 on Ambient Air Quality and Cleaner Air for Europe, available at https://eur-lex.europa. eu/legal-content/EN/TXT/HTML/?uri=CELEX:32008L0050 (accessed 11 March 2021).

[25] Beddows, D.C.S. \& Harrison, R.M., $\mathrm{PM}_{10}$ and $\mathrm{PM}_{2.5}$ emission factors for non-exhaust particles from road vehicles: Dependence upon vehicle mass and implications for battery electric vehicles. Atmospheric Environment, 244, pp. 117886, 2021.

[26] Eurostat, Electricity and Heat Statistics, Eurostat, available at https://ec.europa.eu/ eurostat/statistics-explained/index.php/Electricity_and_heat_statistics (accessed 3 May 2021).

[27] OECD Statistics, Organisation for Economic Co-operation and Development, available at https://stats.oecd.org/ (accessed 3 May 2021). 